\title{
PENGARUH PENDIDIKAN KESEHATAN TENTANG ASI EKSLUSIF TERHADAP PENINGKATAN PENGETAHUAN IBU DALAM PEMEBERIAN ASI EKSLUSIF DI PMB HJ. SULINI DENPASAR
}

\author{
Pande Putu Novi Ekajayanti ${ }^{1,2}$, Pande Putu Indah Purnamayanthi ${ }^{1,2}$, Ni Putu Wiwik Diah Larasati ${ }^{1,2}$ \\ ${ }^{1}$ Program Studi DIII Kebidanan, ${ }^{2}$ STIKES Bina Usada Bali \\ Korespondensi penulis: pandeindah25@gmail.com
}

\begin{abstract}
Abstrak
Latar belakang dan tujuan: Pendidikan Kesehatan diharapkan dapat meningkatkan pengetahuan Ibu Nifas dalam Pemberian ASI eksklusif. Direktur Jenderal Bina Gizi dan Kesehatan Ibu dan Anak Kementrian Kesehatan Slamet Riyadi Yuwono menyebutkan, baru ada 33,6 \% bayi umur 0-6 bulan yang mendapatkan ASI eksklusif. Pengetahuan yang dimiliki ibu dapat berpengaruh dalam pemberian ASI eksklusif tersebut. Tujuan penelitian ini adalah untuk mengetahui pengaruh pendidikan kesehatan tentang Asi Eksklusif terhadap peningkatan pengetahuan ibu nifas dalam pemberian ASI Eksklusif di PMB Hj.Sulini, Denpasar. Metode: Penelitian ini menggunakan desain penelitian pra eksperimen one group pre test-post test. Teknik sampling yang digunakan adalah non random sampling purposive dengan melibatkan 30 responden yaitu ibu nifas yang melakukan kunjungan ke PMB Hj. Sulini, Denpasar. Pengumpulan data menggunakan kuesioner dan rencana analisa statistik menggunakan uji Wilcoxon Matched Pair. Hasil: Hasil penelitian yang diperoleh yaitu nilai $\mathrm{Z}$ sebesar - 5,208 dengan $\mathrm{P}$ value 0,000 dan menggunakan tingkat kepercayaan $\alpha=0,05$. Nilai $\mathrm{P}$ value $0,000<\alpha$ sehingga Ho ditolak dan Ha diterima. Simpulan: ada pengaruh pendidikan kesehatan tentang asi eksklusif terhadap peningkatan pengetahuan ibu nifas dalam pemberian ASI Eksklusif di Praktik Mandiri Bidan (PMB) Hj. Sulini, Denpasar.
\end{abstract}

Kata kunci: ASI Eksklusif, Ibu Nifas, Pendidikan Kesehatan, Pengetahuan

1. Pendahuluan

Upaya Perbaikan Gizi Keluarga (UPGK) yang bertujuan untuk meningkatkan status gizi masyarakat, diprioritaskan pada kelompok masyarakat resiko tinggi yaitu golongan bayi, balita, usia sekolah, remaja, ibu hamil, ibu menyusui, serta usia lanjut. UPGK pada bayi dimulai sejak dalam kandungan. ASI diberikan sejak usia dini, terutama pada pemberian ASI Eksklusif yaitu pemberian hanya ASI pada bayi baru lahir sampai usia 6 bulan. Pemberian ASI secara eksklusif dapat mempercepat penurunan angka kematian bayi dan sekaligus meningkatkan status gizi masyarakat (Depkes, 2006).

Untuk mengatasi masalah tersebut masyarakat harus tahu, terutama para ibu-ibu yang sedang menyusui dan mempunyai bayi. Maka dari itu petugas kesehatan harus memberikan informasi dan promosi kesehatan tentang pentingnya pemberian ASI Eksklusif pada bayi yang berumur 0-6 bulan tanpa memberikan makanan tambahan. Peneliti melakukan promosi kesehatan tentang ASI eksklusif dengan cara memberikan pendidikan kesehatan tentang ASI eksklusif dengan peningkatan pengetahuan ibu nifas untuk memberikan ASI eksklusif (Welford, 2001).

Pada hakekatnya membicarakan istilah pendidikan kesehatan dengan promosi kesehatan itu berbeda artinya. Penekanan promosi kesehatan berdasarkan pemikiran WHO, adalah pada enpowerment atau pemberdayaan. Istilah pemberdayaan ini, diartikan sebagai suatu kegiatan positif yang berkesinambungan (sustainable), dalam hal ini ialah prilaku sehat yang terjadi sebagai hasil promosi kesehatan harus berlangsung terus menerus, sambung menyambung, dari orang, kelompok, atau masyarakat pertama ke orang, kelompok atau masyarakat kedua, ketiga, dan seterusnya, karena peserta didik yang telah berhasil mengubah perilakunya menjadi perilaku sehat akan menularkan 
pendidikan kesehatannya kepada orang lain, kelompok lain, atau masyarakat lain. Pada pendidikan kesehatan maka pada pendidikan masyarakat telah berhasil mengubah perilaku peserta didik menjadi perilaku sehat, (Rakhmad, 2011).

Pendidikan kesehatan adalah suatu proses perubahan pada diri manusia yang ada hubungannya dengan tercapainya tujuan kesehatan perorangan dan masyarakat. Pendidikan kesehatan bukanlah suatu yang dapat diberikan oleh seseorang kepada orang lain dan bukan pula sesuatu rangkaian tata laksana yang akan dilaksanakan ataupun hasil yang akan dicapai, melainkan suatu proses perkembangan yang selalu berubah secara dinamis dimana seseorang dapat menerima atau menolak keterangan baru, sikap baru dan prilaku baru yang ada hubungannya dengan tujuan hidup (Rakhmad, 2011).

Salah satu cara untuk meningkatkan peran aktif ibu nifas dalam mensukseskan ASI Eksklusif adalah dengan meningkatkan pengetahuan ibu nifas melalui pendidikan kesehatan. Pengetahuan merupakan domain yang sangat penting untuk terbentuknya tindakan seseorang. Perilaku yang didasari oleh pengetahuan akan lebih langgeng daripada perilaku yang tidak didasari oleh pengetahuan sehingga diharapkan melalui peningkatan pengetahuan tersebut akan terbentuk sikap positif suami terhadap kehamilan dan persalinan (Yohana, 2008).

ASI merupakan makanan terbaik bagi bayi, karena mengandung zat gizi yang paling sesuai dengan kebutuhan bayi yang sedang dalam tahap percepatan tumbuh kembang, terutama pada 2 tahun pertama dan ASI memberikan seperangkat zat perlindungan terhadap berbagai penyakit akut dan kronis. Memberikan interaksi psikologi yang kuat dan adekuat antara ibu dan bayi yang merupakan kebutuhan dasar tumbuh kembang bayi. Ibu yang menyusui juga memperoleh manfaat menjadi lebih sehat, antara lain menjarangkan kehamilan, menurunkan resiko perdarahan pasca persalinan, anemi, kanker payudara dan indung telur (Sulistyawati, 2009).
Manfaat ASI bagi kesehatan bayi maupun anak sudah banyak diinformasikan kepada masyarakat, tetapi umumnya hanya bersifat global. Sebenarnya yang dibutuhkan oleh masyarakat saat ini adalah informasi rinci yang berbasis bukti ilmiah terpercaya. Tidak dapat dipungkiri para penggerak peningkatan pemberian ASI Eksklusif masih harus bekerja keras agar pemberian ASI Eksklusif dapat lebih ditingkatkan pada ibuibu (Welford, 2001).

Untuk mendukung hal tersebut telah dikeluarkan berbagai pengakuan atau kesepakatan baik yang bersifat global maupun nasional yang bertujuan melindungi, mempromosi, dan mendukung pemberian ASI. Dengan demikian, diharapkan setiap ibu seluruh dunia dapat melaksanakan pemberian ASI dan setiap bayi seluruh dunia memperoleh haknya mendapatkan ASI (air susu ibu) (Kristiyansari, 2009).

Berdasarkan studi pendahuluan yang didapat dari data sekunder di PMB Hj. Sulini Denpasar pada tahun 2015 terdapat $30 \mathrm{ibu}$ nifas yang berkunjung, tahun 2016 terdapat 35 ibu nifas dan pada tahun 2017 sebanyak 12 ibu nifas yang melakukan kunjungan nifas ke PMB Hj. Sulini, Denpasar. Dari hasil wawancara pada delapan orang ibu nifas yang berkunjung ke PMB Hj. Sulini, Denpasar mengatakan bahwa belum pernah mendapat pendidikan kesehatan tentang ASI eksklusif sehingga merasa pengetahuannya tentang ASI eksklusif masih kurang.

Maka dari itu, kami tertarik untuk melakukan penelitian tentang "Pengaruh pendidikan kesehatan tentang ASI eksklusif terhadap peningkatan pengetahuan ibu nifas dalam memberikan ASI eksklusif di PMB $\mathrm{Hj}$. Sulini, Denpasar" untuk memotivasi serta menumbuhkan kemauan dalam memberikan bayinya ASI Eksklusif dari umur 0-6 bulan tanpa makanan pendamping apapun.

\section{Metode Penelitian}

Penelitian yang digunakan merupakan rancangan pra eksperimental dengan one group pre test dan post test desain. Pengisian kuesioner dilakukan 2 kali, kelompok yg sebelum diberikan pendidikan kesehatan 
tentang ASI Ekslusif (01), perlakuan (X) dan kelompok yang sesudah diberikan pendidikan kesehatan tentang ASI Ekslusif (02). Perbedaan 01 dan 02 diasumsikan merupakan efek pengaruh pendidikan kesehatan tentang ASI Ekslusif yang diberikan. Tidak ada kelompok pembanding (non control group), melainkan sudah dilakukan observasi pertama tentang pendidikan kesehatan tentang ASI Ekslusif. Cara pendekatan berdasarkan waktu yang akan digunakan adalah menggunakan metode prospektif yaitu suatu penelitian dimulai dari variabel penyebab kemudian diikuti akibatnya pada waktu yang akan datang (Notoatmodjo,2010).

\section{Hasil dan Pembahasan}

Tabel 1. Karakterstik Responden Berdasarkan tingkat pendidikan

\begin{tabular}{llrc}
\hline No. & Usia & Frekuensi & Persentase (\%) \\
\hline 1. & Diploma/PT & 3 & 10 \\
2. & SMA & 22 & 73,3 \\
3. & SMP & 5 & 16,7 \\
\hline & Total & $\mathbf{3 0}$ & $\mathbf{1 0 0 , 0}$ \\
\hline
\end{tabular}

Tabel 2. Karakteristik responden berdasakan umur

\begin{tabular}{cccc}
\hline No. & Umur & Frekuensi & Persentase (\%) \\
\hline 1 & $20-25$ tahun & 8 & 26,7 \\
\hline 2 & $26-30$ tahun & 4 & 13,3 \\
\hline 3 & $31-35$ tahun & 18 & 60 \\
\hline & Total & $\mathbf{3 0}$ & $\mathbf{1 0 0 , 0}$ \\
\hline \multicolumn{4}{c}{ Karakteristik responden berdasarkan paritas } \\
\hline \multicolumn{2}{c}{ Paritas } & Frekuensi & Persentase (\%) \\
\hline 1 & 7 & 23,3 \\
\hline 2 & 23 & $\mathbf{1 0 0 , 0}$ \\
\hline
\end{tabular}

3.

Tabel

Berdasarkan Tabel 1 terlihat bahwa responden yang berpendidikan paling banyak yaitu SMA sebanyak 22 orang $(73,3 \%)$. Berdasarkan data pada Tabel 2 terlihat bahwa responden terbanyak dari umur 31-35 tahun yaitu $18(60 \%)$ responden. Berdasarkan data pada Tabel 3 dari 30 responden didapatkan paritas Ibu yang terbanyak adalah grandepara sebanyak $23(76,7 \%)$.

Tabel 4. Distribusi frekuensi tingkat pengetahuan sebelum diberikan pendidikan kesehatan

\begin{tabular}{ccc}
\hline & Sebelum diberikan Pendidikan Kesehatan \\
\hline Kategori & Frekuensi (f) & Persentase (\%) \\
\hline Baik & 2 & $7 \%$ \\
Cukup & 20 & $67 \%$ \\
Kurang & 8 & $26 \%$ \\
\hline Total & $\mathbf{3 0}$ & $\mathbf{1 0 0 \%}$ \\
\hline
\end{tabular}


Tabel 5. Distribusi frekuensi tingkat pengetahuan setelah diberikan pendidikan kesehatan

\begin{tabular}{ccc}
\hline & \multicolumn{2}{c}{ Setelah diberikan Pendidikan Kesehatan } \\
\hline Kategori & Frekuensi (f) & Persentase (\%) \\
\hline Baik & 22 & $73 \%$ \\
Cukup & 8 & $27 \%$ \\
Kurang & 0 & $0 \%$ \\
\hline Total & $\mathbf{3 0}$ & $\mathbf{1 0 0 \%}$ \\
\hline
\end{tabular}

Berdasarkan Tabel 4 diketahui tingkat pengetahuan sebelum diberikan pendidikan kesehatan yaitu tingkat pengetahuan kurang sebanyak 8 orang (26\%), kategori cukup sebanyak 20 orang $(67 \%)$, dan kategori baik sebanyak 2 orang (7\%). Sedangkan pada
Tabel 5 terlihat bahwa tingkat pengetahuan responden setelah diberikan pendidikan kesehatan yaitu tingkat pengetahuan kategori cukup sebanyak 8 orang (27\%), dan kategori baik sebanyak 22 orang $(73 \%)$.

Tabel 6. Perbedaan Tingkat Pengetahuan Responden Sebelum dan Setelah Diberikan pendidikan kesehatan tentang ASI eksklusif dengan menggunakan Wilcoxon

\begin{tabular}{ccccc}
\hline No & Kategori & $\begin{array}{c}\text { Tingkat } \\
\text { Pengetahuan } \\
\text { Sebelum } \\
\text { Penyuluhan }\end{array}$ & $\begin{array}{c}\text { Tingkat } \\
\text { Pengetahuan } \\
\text { Setelah } \\
\text { Penyuluhan }\end{array}$ & Pre-Post \\
\hline 1 & Baik & 2 & 22 & \\
\hline 2 & Cukup & 20 & 8 & \\
\hline 3 & Kurang & 8 & 0 & $-5,208$ \\
\hline & Z & & 0,000 \\
\hline
\end{tabular}

Berdasarkan data pada tabel di atas hasil uji statistik menggunakan Wilcoxon Match Pair diperoleh $P$ value sebesar 0,000 dan $\alpha 0,05$ yang berarti $P$ value lebih kecil dari $\alpha$. Hasil ini menunjukkan bahwa ada pengaruh pendidikan kesehatan tentang ASI Eksklusif terhadap peningkatan pengetahuan ibu nifas dalam pemberian ASI Eksklusif di PMB Hj.Sulini Denpasar.

\section{Pembahasan}

Pendidikan kesehatan adalah suatu proses perubahan pada diri manusia yang ada hubungannya dengan tercapainya tujuan kesehatan perorangan dan masyarakat. Pendidikan kesehatan bukanlah suatu yang dapat diberikan oleh seseorang kepada orang lain dan bukan pula sesuatu rangkaian tata laksana yang akan dilaksanakan ataupun hasil yang akan dicapai, melainkan suatu proses perkembangan yang selalu berubah secara dinamis dimana seseorang dapat menerima atau menolak keterangan baru, sikap baru dan prilaku baru yang ada hubungannya dengan tujuan hidup (Rakhmad, 2011).

ASI eksklusif adalah bayi hanya diberikan ASI saja, tanpa tambahan cairan lain seperti susu formula, jeruk, madu, air teh, air putih, dan tanpa makanan tambahan lain seperti pisang, papaya, bubur susu, biskuit, bubur nasi dan tim. Pemberian ASI Eksklusif ini dianjurkan sampai bayi berusia 6 bulan, setelah bayi berumur 6 bulan dia harus mulai diperkenalkan dengan makanan padat, sedangkan ASI dapat diberikan sampai bayi berusia 2 tahun (Roesli, 2007).

Untuk memberikan ASI eksklusif diperlukan adanya tingkat pengetahuan yang baik harus dimiliki oleh orang tua, khususnya dalam periode masa nifas ini. Pengetahuan merupakan faktor penting yang mempengaruhi sikap dan perilaku seseorang. Kurangnya pengetahuan dapat berpengaruh pada tindakan yang dilakukan karena pengetahuan merupakan salah satu faktor predisposisi untuk terjadinya perilaku. Dengan diberikan pendidikan kesehatan 
diharapkan terjadi peningkatan pengetahuan dari yang semula belum tahu menjadi tahu (Nirmawana, 2011; Pulungan, 2008).

Berdasarkan hasil penelitian sebelum diberikan pendidikan kesehatan tentang ASI eksklusif, diperoleh responden dengan tingkat pengetahuan kurang sebanyak 8 orang $(26 \%)$, kategori cukup sebanyak 20 orang $(67 \%)$, dan kategori baik sebanyak 2 orang $(7 \%)$. Setelah diberikan pendidikan kesehatan tentang ASI Eksklusif didapatkan responden dengan tingkat pengetahuan kategori cukup sebanyak 8 orang $(27 \%)$, dan kategori baik sebanyak 22 orang (73\%).

Setelah diberikan perlakuan berupa pendidikan kesehatan tentang ASI eksklusif terjadi perubahaan komposisi kategori tingkat pengetahuan ibu nifas. Terdapat 22 orang yang mengalami perubahan tingkat pengetahuan menjadi baik dan 8 orang dalam kategori cukup serta dipertegas dengan pengujian statistik menggunakan Wilcoxon test diperoleh nilai $\mathrm{p}$ sebesar 0,000 . Hal ini berarti Ha diterima atau dengan kata lain ada pengaruh pendidikan kesehatan ASI eksklusif terhadap peningkatan pengetahuan Ibu Nifas dalam memberikan ASI eksklusif di PMB Hj. Sulini, Denpasar. Ini tidak terlepas dari tingkat pendidikan responden kategori menengah sebesar 73,3\% dimana tingkat pendidikan akan mempengaruhi daya serap tentang materi pendidikan kesehatan ASI eksklusif, begitu pula umur juga mempengaruhinya dimana umur responden yang sebagian besar adalah kelompok dewasa, hal ini berkaitan dengan daya nalar yang lebih baik, dan dari segi paritas dikaitkan dengan pengalaman hidup, sehingga pengalaman anak pertama menjadi pengalaman untuk anak berikutnya. Menurut Roesli (2008), menyatakan bahwa pendidikan ibu yang relatif kurang dapat menurunkan perilaku pemberian ASI eksklusif.

Untuk meningkatkan perilaku ibu menyusui perlu dilakukan intervensi dengan meningkatkan penyuluhan tentang ASI eksklusif. Hal ini sesuai dengan teori komunikasi bahwa efektif tidaknya penyuluhan maupun pendidikan kesehatan tergantung pada pencapaian tujuan pemberian penyuluhan itu sendiri. Dalam hal ini memiliki tujuan untuk mengubah prilaku ibu menyusui. Pada konteks ini efektivitas prilaku bisa diukur dari sejauh mana perubahan rata-rata penilaian perilaku responden sebelum dan sesudah pemberian pendidikan kesehatan. Menurut Notoatmodjo (2002), sejalan dengan perkembangan manusia cara berfikir manusia pun ikut berkembang, dari sini manusia dapat menggunakan cara penalarannya dalam memperoleh pengetahuannya.

\section{Simpulan}

Berdasarkan hasil penelitian dan pembahasan dapat disimpulkan bahwa responden sebelum diberikan pendidikan kesehatan tentang ASI Eksklusif dengan tingkat pengetahuan kurang sebanyak 8 orang $(26 \%)$, kategori cukup sebanyak 20 orang $(67 \%)$, dan kategori baik sebanyak 2 orang $(7 \%)$. Setelah diberikan pendidikan kesehatan tentang ASI Eksklusif responden dengan kategori cukup sebanyak 8 orang $(27 \%)$, dan kategori baik sebanyak 22 orang $(73 \%)$.

Pendidikan kesehatan ASI Eksklusif berpengaruh secara signifikan terhadap peningkatan pengetahuan Ibu Nifas dalam pemberian ASI eksklusif di PMB Hj.Sulini Denpasar, yang ditandai dengan nilai $\mathrm{P}$ value sebesar 0,000 . Tingkat pengetahuan seorang ibu nifas sangat berperan penting dalam pemberian ASI eksklusif kepada bayinya. Karena memberikan ASI eksklusif pada bayi sangat bermanfaat bagi ibu dan bayi.

\section{Referensi}

Ambarwati. 2008. Asuhan Kebidanan Ibu dan Anak. Available from: http//www. Ambarblogspot. com. accessed. January 17.2018.

Arikunto. 2002. Pengantar Metode Penelitian. Jakarta: Rineka Cipta.

Arikunto. 2005. Metode Penelitian. Jakarta: Rineka Cipta.

Arikunto. S. 2010. Prosedur Penelitian suatu Pendekatan Praktik. Edisi Revisi. Jakarta : Rineka Cipta. 
Basuki. 2006. Efektivitas Metode Ceramah Terhadap Peningkatan Pengetahuan. Retrieved Februari 18, 2018, http://repository.usu.ac.id.

Budiman, dr. 2011. Metode Penelitian. Jakarta: Nuha Medika.

Chandra, B. 2008. Metodologi Penelitian Kesehatan. Jakarta : EGC.

Christine, Henderson. 2006. Buku Ajar Konsep Kebidanan. Jakarta: EGC.

Depkes, RI. 2006. Permasalahan Dalam Pemberian Makanan Bayi. Meneg Pemerdayaan Perempuan, Ikatan Dokter Anak Indonesia, BK PP-ASI dan Lintas Program.

Depkes. 2002. Petunjuk Pelaksanaan Penetapan Indikator Menuju Indonesia Sehat 2010. Jakarta : Depkes RI.

Effendy. 2003. Penyuluhan Kesehatan. Retrieved Februari 18, 2018, http://www.muchlisheffendy.wordpre ss.com.

Fitriani, S. 2011. Promosi Kesehatan. Edisi Pertama. Yogyakarta : EGC.

Hegar, Badrul. 2008. Bedah ASI. Jakarta: Balai Penerbit FKUI.

Herawati. 2009. Ibu Dan Anak. Jakarta: Salemba Medika.

Hidayat. 2009. Metode Penelitian Kebidanan dan Teknik Analisa Data. Jakarta: Salemba Medika.

Janah, Nurul. 2011. Asuhan Kebidanan Ibu Nifas. Jogyakarta: AR-RUZZ Media.

Kementrian Kesehatan. 2010. Rencana Strategis Kementrian Kesehatan Tahun 2010-2014. Jakarta : Kementrian Kesehatan RI.

Kristiyansari, Weni. 2009. ASI, Menyusui dan SADARI. Yogjakarta: Nuha Medika.

Manuaba, Ida Bagus Gede. 2003. Buku Ajar Ginekologi Untuk Mahasiswa Kebidanan. Jakarta: EGC.

Marimbi, Hanum. 2010. Tumbuh Kembang, Status Gizi, Dan Imunisasi Dasar Pada Balita. Jakarta: Salemba Medika.

Nursalam. 2003. Konsep Dan Penerapan Metodelogi Penelitian Ilmu
Keperawatan. Jakarta: Salemba Medika.

Nolan, M. 2004. Kehamilan Dan Melahirkan. Jakarta : Arcan.

Notoatmodjo, S. 2003. Pendidikan dan Perilaku Kesehatan. Edisi Revisi. Jakarta : EGC.

Notoatmodjo, S. 2010. Metode Penelitian Kesehatan. Edisi Revisi. Jakarta : Rineka Cipta.

Nursalam. 2003. Konsep dan Penerapan Metodologi Penelitian Ilmu Keperawatan. Edisi Pertama. Jakarta : Salemba Medika.

Poverawati, Atikah, dkk. 2010. Kapita Selekta ASI dan Menyusui. Yogyakarta: Nuha Medika.

Prawiroharjo, Sarwono. 2007. Ilmu Kebidanan. Jakarta: PT Bina Pustaka Sarwono Prawiroharjo.

Pulungan, R. 2008. Pengaruh Metode Penyuluhan Terhadap Peningkatan Pengetahuan dan Sikap Dokter Kecil dalam Pemberantasan Sarang Nyamuk Demam Berdarah (PSNDBD) di Kecamatan Helvetia Tahun 2007, Tesis. Sekolah Pasca Sarjana Universitas Sumatera, Medan. Retrieved Maret 11, 2018, Http://creasoft.com.

Rakhmad, Susilo. 2011. ASI Eksklusif. Avaibel from: http//alam-hadi. Blogspot. Com/2011/07/ASI eksklusif.html.accesed: februari 18 . 2018.

Riwidikdo, Handoko. 2007. Statistik Kesehatan. Jogyakarta: Mitra Cendikia.

Riyanto, A. 2009. Pengolahan dan Analisis Data Kesehatan. Yogyakarta : Nuha medika.

Riyanto, Agus. 2011. Aplikasi Metodelogi Penelitian Kesehatan. Yogyakarta: Nuha Medika.

Roesli, Utami. 2007. Bayi Sehat Berkat ASI Eksklusif. Jakarta: PT. Elex Media Komputindo.

Roesli, Utami. 2009. ASI Eksklusif. Jakarta: PT. Elex Media Komputindo.

Rosita, Syarifah. 2008. ASI Untuk 
Kecerdasan Bayi. Yogyakarta: Ahyana.

Saryono, Ari Setiawan. 2011. Metodelogi Penelitian Kebidanan DIII, DIV, SI dan S2. Yogyakarta: Nuri Medika.

Silisno. 2009. Metode Penelitian. Salemba: Maha Medika.

Sugiyono. 2010. Statistika Untuk Penelitian. Edisi Revisi. Bandung : Alfabeta.

Sugiyono. 2011. Metode Penelitian Pendidikan (Pendekatan Kuantitatif, Kualitatif, dan $R \& D)$. Bandung: Alfabeta, Bandung.

Suyanto dan Ummi Salamah. 2009. Riset Kebidanan Metodologi dan Aplikasi. Yogyakarta : Mitra Cendikia Press.

Welford, Heather. 2001. Menyusui Bayi Anda. Edition Development Ltd, London, UK. Dian Rakyat.

Yetti, Anggraini. 2010. Air Susu Ibu. Available from: http//www.balipost.co.id. Accessed January 172018 